DOI:10.17951/h.2016.50.1.135

\begin{tabular}{lcc}
\hline \multicolumn{3}{c}{ A N N A L E S } \\
UNIVERSITATIS MARIAE CURIE-SKŁODOWSKA \\
LUBLIN - POLONIA \\
VOL. L, $1 \quad$ SECTIOH \\
\hline
\end{tabular}

WSB University in Poznań. Faculty of Finance and Banking

WIESŁAWA ZIÓŁKOWSKA

wieslawajoanna@poczta.onet.pl

\title{
Economic Activity and the Correlation between Taxes and the General Government Sector Debt
}

$\overline{\text { Aktywność gospodarcza a korelacja między podatkami i długiem sektora general government }}$

Keywords: taxes; balance; general government sector debt; correlation; Pearson coefficient Słowa kluczowe: podatki, saldo i dług sektora general government, korelacja, współczynnik Pearsona

JEL Code: G32; G38

\section{Introduction}

This paper aims to answer the question whether the strength and direction of the relationships between taxes, the deficit and the general government sector debt vary in different periods of economic activity. The alternating periods of acceleration and slowdown of the economy are a natural phenomenon which occurs on and off in a market economy. The prevailing view is that those fluctuations cannot be avoided. However, they may be mitigated and their course flattened if the intervals at which they happen and their duration is shortened, which may be achieved through better control of the level and structure of revenues and expenses. For over twenty years, economic activity at different levels has been accompanied by chronic deficits, which has eventually led to the globalisation of debt. One of the reasons for the growth of this debt is declining taxes which are the one of the sources of the global debt. Thus, to increase the efficiency of fiscal tools it seems necessary, among other things, first to examine the mutual dependencies between taxes, the deficit and debt of the public finance sector. 
The analysis presented here covers the years 1995-2014 and the EU states with a particular focus on Poland. For the purpose of his paper these years were basically divided into two sub-periods: (I) the years 1995-2007 were times of a prosperity in economy with a slowdown (downturn) in 2001-2002; while (II) the period 20082014 was a time of a relatively long-lasting economic crisis.

\section{Public debt and economic activity}

The years 1995-2007 were a period of a gradual growth of the real gross domestic product. The dynamics of the EU's GDP was at $2.5 \%$ and came to a halt in 2002 when it stopped at $2.2 \%$ and fell further in the next two years to $1.3 \%$ in 2002 and $1.5 \%$ in 2003 . This was mainly the effect of the crisis in the IT market, which in other sectors of the economy was already felt in 2001. The growth rate of 2000 was recovered only in 2006-2007, but this boom in the economy was short-lived and was followed by a rapid economic downturn, the scale, nature and persistence of which left many economists startled.

Countries of Eastern and Central Europe which had experienced an economic crisis resulting from the political transformation of their regimes at the beginning of the nineties, found themselves less affected, having their economies generally less developed and therefore less sensitive. Their average growth in the GDP in 1996-2007 was $4.5 \%$ oscillating between $1.1 \%$ in 1999 and $7.3 \%$ and $7.1 \%$ between 2006 and 2007. The average dynamics of the GDP in Poland was almost the same as in the whole region. However, after a higher growth in years 1996-1997, Polish economy experienced a rapid turndown resulting, largely, from the Russian crisis and its negative impact on Russia's balance of trade and financial stability. Initially, the negative effects were mainly observed in the decline in the growth dynamics by about $2 \%$ points. Subsequent wrong decisions in economic policy, however, and the underestimations of the cost of Poland's four big reforms: in administration, health care, social policy and education, led to a further decline in the growth rate to $1.2 \%$ and $2.0 \%$ in the years 2001-2002. The period 2004-2007 was a good economic time, slightly worse in 2005 , but showing the highest till then, since the beginning of the transformation process, increase in the GDP of $6.2 \%$ and $7.2 \%$ in 2006 and 2007 respectively. The apparent slowdown of its dynamics after 2007 was already the effect of the global crisis which, as it turned out, was very long-lasting.

Despite such irregular and yet continuous growth tendency measured as the real GDP between 1996-2007, the average balance of the government sector EU-wide was negative, accounting for 2.2\% GDP. Deficit in Eastern and Central European countries in the same period was even higher, reaching annual average 3.0\% GDP. In Poland, with its $4.6 \%$ economic growth, the negative annual average balance of public finances was $4.1 \%$ GDP. The deficits in other countries resulted in an increased debt of the general government sector, although its impact was less felt in countries 
with stronger economies. In EU28, the percent of the general government sector debt in the GDP declined on average by $9.1 \%$ points vis à vis an increase in ECE by $0.8 \%$ points. The extremely varying levels of indebtedness of individual countries during the relatively good economic time is illustrated in fig. 1 .

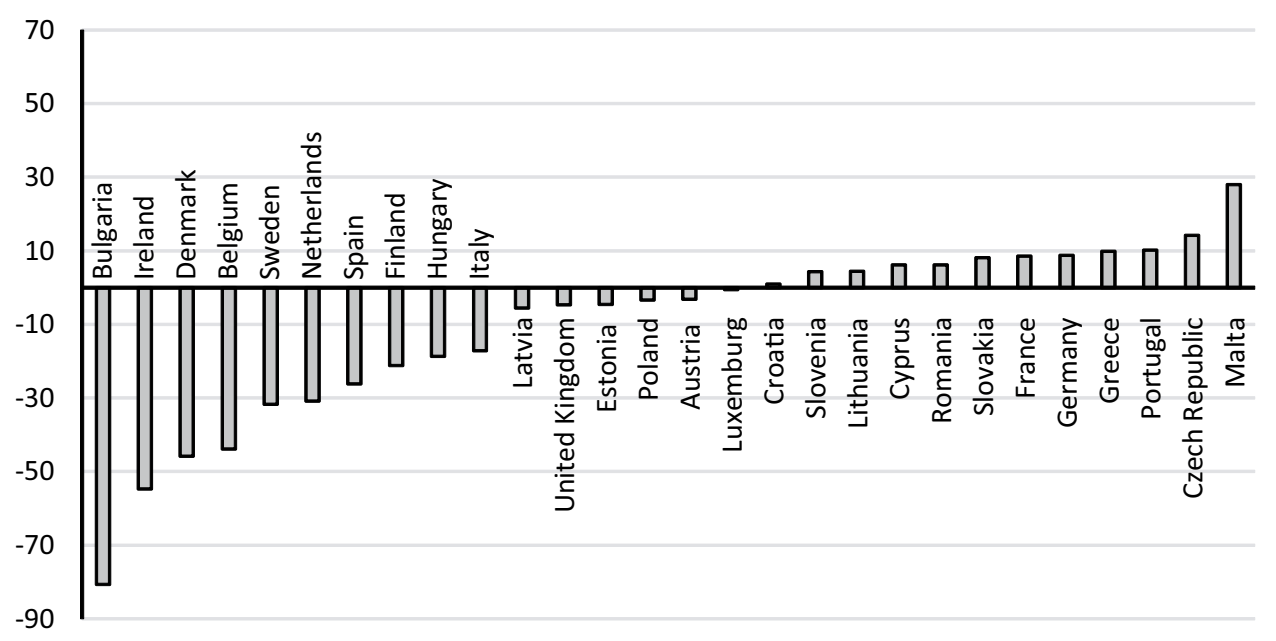

Fig. 1. Cumulated change in the share of the general government sector debt in GDP expressed in percent points between $1995-2007 *$

* differences between the debt to the GDP relationship as of the end of 2007 and 1995

Source: own calculations based on the Eurostat and Ameco data.

In Poland, the years 1995-2007 showed a decline in the debt as a percent of GDP by $3.4 \%$ points. This was the result of restrictive spending policy which enabled Poland to reduce its 1998-2000 debt, placing it among the lower level public debts of the EU Member states.

The years 2007-2008 were the beginning of a financial crisis, first in the USA. The crisis had gradually deepened and turned out to become a global one. If in 2008 the real GDP dynamics was negative only in 8 Member states, in the following year it was already on the decline in all the remaining states but Poland. In 2009 the average negative dynamics of the GDP in the EU was $4.4 \%$ and in ECE it was $7.7 \%$. In Poland, the growth in GDP slowed down from $7.2 \%$ in 2007 to $2.6 \%$ in 2009 . Between the years 2008-2014 the average dynamics of the GDP in the entire EU was only $0.1 \%$, in ECE it was $0.5 \%$ and in Poland 3.1\% of GDP. This was, of course, accompanied by a cumulating negative balance of the sector which in the years 2008-2014 oscillated between 7.6\% of GDP in 2010 and 3.2\% of GDP in 2014. These long-lasting deficits brought about an increased percent of the general government debt in GDP, which then, within the EU28 was 77.00 on average. 
138 WIESŁAWA ZIÓŁKOWSKA

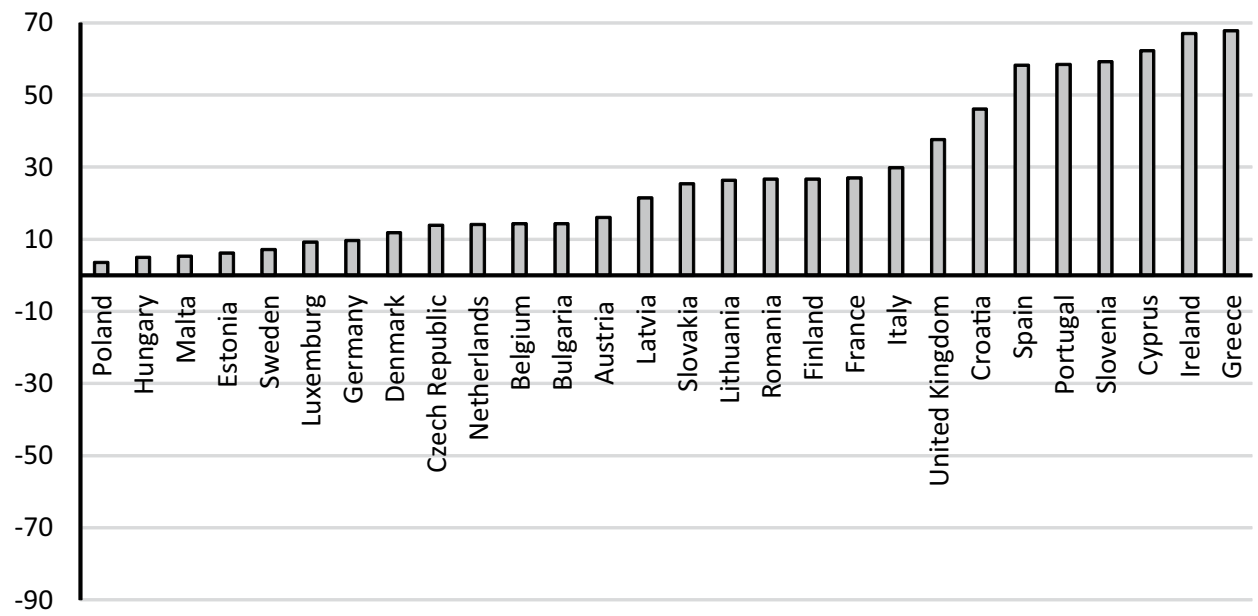

Fig. 2. Cumulated change in the share of the general government sector debt in GDP expressed in percent points during 2008-2014*

* differences between the debt to the GDP relationship as of the end of 2014 and 2008

Source: own calculations based on the Eurostat and Ameco data.

In Poland, the increase in the national debt was the lowest, despite the fact that the percent of the average public debt at the time of the economic turndown was $52.5 \%$ GDP. Once the debt in GDP ratio had reached the highest level since 1995, accounting for $55.7 \%$ as of the end of 2013 , it then declined to $50.1 \%$ in the GDP in the following year, which was caused by the changes arising from the reform of the pension system ${ }^{1}$. The changes in the economic activity happening between 1995-2014 were also a period of transformation of the fiscal policy, and resulted from, in particular:

- weakened automatic stabilisers of prosperity caused by declining tax progression and the fixing of expenditures ${ }^{2}$, significant cuts in tax rates ${ }^{3}$,

- difficulty of applying an economic calculation to serve as a tool for stimulating changes that are beneficial to citizens regarding the quantity and qu-

1 The changes in the pension system, which entailed redemption of PLN 130 billion in treasury bonds induced a change in the level and structure of the debt.

2 In Pikett's opinion, the result of a growing fiscal competition is an unprecedented development of tax exemptions pertaining to capital revenues. Consequently, in most countries, the tax system becomes regressive at the top of the income hierarchy [Piketty, 2015, p. 615-616].

3 In the EU the difference in 2014 and in 1995 between the top income tax rates from individuals was on average $7.8 \%$ points (in Poland $13 \%$ points), and between the corporate income tax on average $12.1 \%$ points (in Poland $-21 \%$ ). 
ality of goods and services financed by public funds [Lubińska, Strąk, 2011, p. 52-59],

- growing income inequalities resulting from the implemented fiscal policy [Brzeziński, 2014, p. 121-136],

- chronic budget deficits in both phases of the economic cycle ${ }^{4}$,

- a rapid increase in the general government sector debt,

- global character of the public debt and changes in its financing ${ }^{5}$,

- low effectiveness of fiscal policy in the main revenue centres, mainly due to its tendency to forward tax cuts in order to increase market competitiveness, as illustrated in fig. 3 .

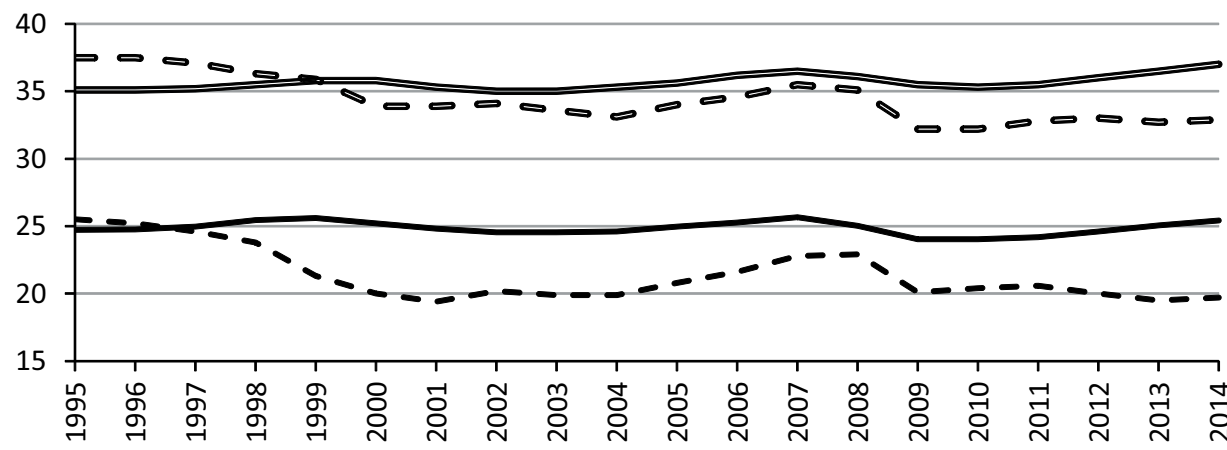

\footnotetext{
- Taxes on production and imports and taxes on income and wealth EU28

- - Taxes on production and imports and taxes on income and wealth Poland

Taxes and social insurance contributions EU28

- Taxes and social insurance contributions Poland
}

Fig. 3. Taxes and social insurance contributions in the EU28 and in Poland as \% GDP

Source: own calculations based on Eurostat.

It may be concluded, in these circumstances even if it is a certain simplification of the issue, that the main dilemma of the fiscal policy is its implementation and realisation under the conditions of a high public debt. This is because in practice as well as in theory, the rather common view is that tax cuts cause a growing debt. Hence the objective of this paper to examine the relationship between taxes, the budget deficit and the public debt seems well grounded.

4 Out of 553 annual budgets of EU Member states between 1995-2014 only 84 showed a surplus, and 5 were balanced. Budgets with a surplus were found mainly in wealthy countries: Luxemburg, Finland, Sweden, Denmark and Germany, although also in Estonia and Bulgaria.

5 In P.H. Dembinski's opinion, this change is based on "an ideological consensus that maintaining the value of borrowed capital is more important that the relief for those burdened with the obligation to service and repay the debt" [Dembinski, 2012, p. 76-79]. 


\section{Relationships between taxes, the budget balance and the public debt at different stages of economic activity}

In order to establish the strength and direction of the relationships between the variables examined in this paper, an analysis of statistical correlation has been made. With the help of Pearson coefficient, the correlation between the following variables was examined ${ }^{6}$ :

- public funds from two main sources, i.e. taxes on income and wealth and taxes on production and import $(\mathrm{X})$ with the balance $(\mathrm{Y})$ and debt $\left(\mathrm{Y}^{\prime}\right)$ of the general sector government measured as their share in the gross domestic product,

- total tax burdens including social insurance contributions (X') with the balance (Y) and the debt (Y') of the general government sector as a percent of GDP.

The study began with an analysis of the relationship between the revenues from two main tax sources (X) and the balance (Y) in relation to GDP at economic prosperity $(\mathrm{P})$ and at the time of a financial crisis $(\mathrm{C})$. The following results were obtained (for better clarity they are presented here parallel for both periods " $\mathrm{P}$ " (prosperity) and "C" (crisis)):

1) No correlation was observed:

P: in 5 countries: Estonia, Denmark, Ireland, Finland and Poland,

C: in 3 countries: Estonia, Lithuania and Poland.

2) A weak correlation was observed:

P: in 5 countries: Slovakia, Latvia, Bulgaria, the Czech Republic and the Netherlands, of which a positive correlation was observed in 3 cases and negative in the other 2 countries,

C: in 6 cases: Finland, the Netherlands, Slovenia, Denmark and Hungary, a positive correlation was noted, and a negative one in Luxemburg.

3) Average correlation existed:

P: in 13 countries: 11 with a positive correlation: Germany, Austria, Luxemburg, Belgium, Hungary, Portugal, Greece, Cyprus, Croatia, Slovenia, Sweden and 2 cases with a negative correlation: Lithuania, Romania,

C: in 9 countries: Belgium, Great Britain, Sweden, Malta, Spain, Greece, Ireland, Bulgaria and the Czech Republic the correlation indicated a positive direction.

4) A strong or very strong positive correlation was noted:

P: in 5 countries: Malta, Great Britain, Italy, Spain, France,

C: in 10 countries: Italy, France, Austria, Croatia, Cyprus, Portugal, Germany, Latvia, Romania, Slovakia.

6 The interpretation of the strength of the correlation was based on the following coefficient values: 0-20 no correlation, 20-40 correlation exits but is weak, 40-70 average correlation, 70-90 strong correlation, other influences unclear, $90-100$ very strong influence. 
In another examination the relationship between total tax receipts including insurance contribution ( $\left.X^{\prime}\right)$ and the balance of the general government sector (Y) as percent in GDP were analysed, and the following results were obtained:

1) No correlation:

P: in 10 countries this correlation was fund to be only accidental, these countries were: Latvia, Ireland, Denmark, Greece, Germany, Belgium, Sweden, the Netherlands, the Czech Republic and Austria. Eight countries out of those 10 were member states of the former EEC. An interesting conclusion that may be drawn based on this result is that in a relatively large number of countries there is no correlation between total tax receipts including insurance contribution as percent of GDP and the deficit of the general government sector,

C: in 2 countries: Sweden and Estonia.

2) A weak correlation was noted:

P: in 8 countries, of which 6 showed a positive correlation coefficient: Portugal, Luxemburg, Poland, Italy, Latvia and Bulgaria. A negative coefficient occurred in Romania and Slovenia,

C: in 4 countries: Denmark, Belgium and Romania the coefficient was positive and in Lithuania it was negative.

3) Average correlation:

P: out of 7 countries in which the correlation was average, in 6 the coefficient was positive: Hungary, Croatia, Finland, Estonia, Great Britain, Cyprus and France. In the other 2 the correlation was negative,

C: occurred in 18 countries, and in 15 of them the correlation coefficient was positive: Great Britain, Hungary, Cyprus, Austria, France, Germany, Poland, Italy, Slovakia, Bulgaria, the Netherlands, Malta, Ireland, Spain and Greece. A negative coefficient was noted in Finland, Slovenia and Luxemburg.

4) Strong and very strong correlation was observed:

P: only in 2 countries that showed a positive correlation coefficient: Malta and Spain,

C: in 4 countries with positive correlation: Portugal, Czech Republic, Croatia, Latvia.

Next, the relationship between the same taxes (X) and debt of the general government sector ( $\left.Y^{\prime}\right)$ was analysed as percent in GDP. The results of these analyses were more complex.

1) There was no correlation observed in:

P: 7 very different countries: Lithuania, Belgium, the Netherlands, Sweden, the Czech Republic, Denmark and Poland,

C: 6 countries: Slovakia, Sweden, Ireland, Austria, Croatia and Malta.

2) Weak correlation was noted in: 
P: 6 countries: Hungary, Portugal, Luxemburg, France, Finland showing a positive coefficient, and in Italy with a negative one,

C: 4 countries: Latvia, Bulgaria, Slovenia, Great Britain - negative correlation.

3) Average correlation was found:

P: in 9 countries, of which in 6 the correlation coefficient was negative: Germany, Slovakia, Austria, Greece, Romania and Great Britain. In 3 countries it was positive: Slovenia, Ireland and Cyprus,

C: in 11 countries while the correlation coefficient was positive in 6: Denmark, Belgium, Estonia, Romania, Portugal and Spain, a negative coefficient was in the Netherlands, Cyprus, Germany, Hungary and Poland.

4) strong and very strong correlation:

P: in 6, of which in 4 it was negative: Latvia, Croatia, Bulgaria, Spain, and 2 positive: Malta, Estonia,

C: in 7, of which 6 showed very strong positive correlation: Finland, Luxemburg, France, Italy, Czech Republic, Greece, while in Lithuania it was very strong and negative.

The next relationships analysed were between tax dues including insurance contributions ( $\left.\mathrm{X}^{\prime}\right)$ and public debt (Y'). The following results were obtained:

1) No correlation occurred:

P: in 5 countries which were, what is noteworthy, of diametrically different levels of economic development: Poland, France, Slovenia, Luxemburg and Lithuania,

D: in 8 countries: Ireland, Estonia, Romania, Latvia, Bulgaria, Croatia, Sweden and Malta.

2) weak correlation was found:

P: in 5 countries where 3 showed a negative correlation coefficient: Austria, Latvia and Slovakia and 2 a positive one: Greece and Denmark,

C: in 4 countries: Austria and Slovenia showing a positive coefficient and Cyprus and Germany with a negative one.

3) Average correlation:

P: was noted in 11 countries: Germany and Great Britain where its strength belonged to the top ones and was negative, while a positive coefficient of that correlation occurred in Ireland, Hungary, Sweden, Portugal, Cyprus, Belgium, Italy, Romania and the Czech Republic,

C: occurred in 8 countries: Denmark, Slovakia, Luxemburg, Spain, Portugal, the Netherlands with a positive coefficient and Great Britain and Poland showing negative correlation.

4) Strong correlation was found:

P: in 7 countries and in 3 of them it was positive: Netherlands, Finland, Malta, negative Bulgaria, Estonia and a very strongly negative coefficient in the other 2: Spain, Croatia, 
C: in 8 countries, 6 with positive direction: Belgium, Czech Republic, Italy, Greece, Finland, France and 2 was negative: Hungary, Lithuania.

This detailed presentation of the results of the study, specifying all levels of correlation for all member states and indicating in how many states and with what intensity it occurred univocally shows how different fiscal policies have been implemented and continue to be implemented in individual member states, both during good as well as worse economic times. In the future, this fact may hinder coordination of a fiscal policy within the European Union.

Differences in the intensity of correlation between the variables examined in the years 1995-2007 (P) and 2008-2014 (C) are presented in table 1.

Table 1. Correlation coefficients in the period of prosperity and downturn of economy

\begin{tabular}{|c|c|c|c|c|c|}
\hline \multirow{2}{*}{ Variable } & \multirow{2}{*}{ Period } & \multicolumn{4}{|c|}{ Correlation coefficient (number of countries) } \\
\cline { 2 - 6 } & & Weak & Average & Strong & Very strong \\
\hline \multirow{2}{*}{$\mathrm{X} \leftrightarrow \mathrm{Y}$} & $\mathrm{P}$ & $0.30(5)$ & $0.56(13)$ & $0.81(4)$ & $0.90(1)$ \\
\cline { 2 - 6 } & $\mathrm{C}$ & $0.26(6)$ & $0.62(9)$ & $0.77(10)$ & - \\
\hline \multirow{2}{*}{$\mathrm{X}^{\prime} \leftrightarrow \mathrm{Y}$} & $\mathrm{P}$ & $0.29(8)$ & $0.51(8)$ & $0.70(1)$ & $0.91(1)$ \\
\cline { 2 - 6 } & $\mathrm{C}$ & $0.27(4)$ & $0.56(18)$ & $0.79(4)$ & - \\
\hline \multirow{2}{*}{$\mathrm{X} \leftrightarrow \mathrm{Y}^{\prime}$} & $\mathrm{P}$ & $0.30(6)$ & $0.51(9)$ & $0.78(5)$ & $0.91(1)$ \\
\cline { 2 - 6 } & $\mathrm{C}$ & $0.25(4)$ & $0.58(11)$ & $0.77(6)$ & $0.97(1)$ \\
\hline \multirow{2}{*}{$\mathrm{X}^{\prime} \leftrightarrow \mathrm{Y}^{\prime}$} & $\mathrm{P}$ & $0.30(5)$ & $0.54(11)$ & $0.76(5)$ & $0.91(2)$ \\
\cline { 2 - 6 } & $\mathrm{C}$ & $0.28(4)$ & $0.59(8)$ & $0.82(8)$ & - \\
\hline
\end{tabular}

Source: own calculations based on Eurostat.

The data presented in the table 1 , allows us to formulate the following conclusions:

- at the time of a crisis the mutual relationships, or interdependence between the investigated variables increased and more countries showed an average and strong correlation coefficient,

- during the same time, the number of countries showing weak correlation and countries in which such correlation was not observed decreased.

The findings of the research also show a gradual decline in the number of countries demonstrating negative correlation. Increasing the number of counties demonstrating positive direction in period of crisis then in prosperity, showing that growing taxes in crisis has more essential impact on the deficit, and as a result on public debt.

Thus the correlation between taxes and taxes increased by social insurance contributions and the budget deficit and public debt was different in the prosperity period, when the economy was good, and different when the economy was slowing down. These differences were more visible in the first two analyses in which deficit was one of the variables, and slightly less obvious when the variable investigated was public debt, a variable more determined than deficit. 
Regarding Poland, the first analysis did not show any correlation between taxes and budget deficit either at the time of increased economic activity or its downturn. This means that Polish budget deficit was under a strong influence of expenditures. The correlation between taxes that included social insurance contributions and the budget deficit occurring at the time of a relatively good economic activity turned out to be very weak (0.23) while in the crisis years the intensity of that correlation increased to the average level of 0.59 . This relationship may be interpreted as an average influence of taxes increased by insurance contributions on the budget deficit with an equally strong influence of expenditures on the same. No correlation between taxes and taxes increased by insurance contributions was noted during good economic times. Between 2008 and 2014 the results of both analyses indicated an average negative correlation with coefficients 0.67 and 0.62 of taxes only, and taxes with contributions, respectively. Taxes as well as taxes increased by contributions had average influence on the public debt, while at the same time the influence of other factors was equally strong. Since 2014 changes in public debt have been influenced by the changes in the pension system, clearly lowering the debt level. The average share of taxes in GDP at the time of crisis was over $2 \%$ points lower, while the percent of the deficit in GDP was $0.8 \%$ points higher. Cuts in income tax rates had no effect on the widening of the tax base, resulting in a higher deficit and debt in the general government sector debt.

In all analyses carried out in the research, a positive correlation coefficient was predominant, i.e. the lower (higher) tax burden, the lower (higher) deficit and public debt. It may be thus concluded that the tax rate did not reach the point below which or above which budget receipts start going down. A negative correlation coefficient would suggest a greater probability that, depending on the degree of correlation, the rate of a decrease or increase in tax rates below or above which the budget receipts go down rather than go up, has approached or passed the critical point.

The multi-factor and multi-direction conditioning underlying the effects of a fiscal policy measured as the relation of the balance (almost always negative) and the general government sector debt to the GDP justifies taking measures aiming to determine not so much the optimal or critical points, but the space within changes in tax rates occur. These areas are called here "areas of tax deficiency" which denote areas characterised by too low tax rates for the particular conditions occurring in a given country. A situation opposite to that is too high tax rates, referred to as an "area of tax saturation". Between the two there is an "area of possibly advantageous tax rates" which determines a sustained development on an individual country functioning in certain conditions for a certain length of time ${ }^{7}$.

7 A sustained development includes coherent conceptualization and exploitation of development on economic, social and ecological planes, based on the ethical and moral order. What is needed is a path leading to better welfare (financial status) of citizens, a path where on the one hand the inequalities between the rich and the excluded ones will be eliminated, but on the other hand the relationships between generations relations change, since today, as a result of demographic processes are being worsened, and the process of the natural environment degradation stops [Ziółkowska, 2014, p. 73-86]. 
The change of points into areas is of more than merely formal significance. It is a consequence of accounting for the variety of factors that determine the effects of changes in tax rates ranging from economic, to historic, political, sociological and cultural, including the character (nature) of the external environment over a certain length of time. Thus, in economies of very similar parameters, they may, during the same time, differently influence and determine the relationships between taxes including taxes increased by social insurance contributions and the general government sector debt.

\section{Bibliography}

Brzeziński M., Nierówność dochodowa w Polsce, [in:] B. Kłos, J. Szymańczak (eds.), Nierówności społeczne w Polsce, Wydawnictwo Sejmowe, Warszawa 2014.

Dembinski P.H., Finanse po zawale, Wydawnictwo Studio Emka, Warszawa 2012.

Lubińska T., Strąk T., Paradygmat budżetowania zadaniowego na tle wyzwań nowego zarządzania publicznego, [in:] T. Lubińska (ed.), Kierunki modernizacji zarządzania $w$ jednostkach samorzadu terytorialnego, Difin, Warszawa 2011.

Piketty T., Kapitat w XXI wieku, Wydawnictwo Krytyki Politycznej, Warszawa 2015.

Ziółkowska W., Niektóre aspekty finansów publicznych i zrównoważonego rozwoju w Unii Europejskiej, [in:] S. Owsiak (ed.), Finanse w polityce makroekonomicznej państwa, Wydawnictwo Uniwersytetu Ekonomicznego, Kraków 2014.

\section{Aktywność gospodarcza a korelacja między podatkami i długiem sektora general government}

Autorka analizuje różnice korelacyjne między podatkami $(\mathrm{X})$ i podatkami powiększonymi o składki na ubezpieczenia społeczne (X') a długiem (Y') sektora general government w państwach Unii Europejskiej w dwóch różnych fazach aktywności gospodarczej. Siła istotności badanych zależności w konkretnych warunkach poszczególnych krajów okazała się bardzo różna. We wszystkich badaniach przeważał dodatni kierunek zależności. Oznacza to, że im wyższe były obciążenia podatkowe, tym niższa baza podatkowa i wyższy deficyt i dług publiczny. Tym samym im niższe podatki, tym niższy deficyt i dług. Otrzymane wyniki badania należy interpretować ostrożnie, kategorie mu poddane są bowiem wielostronnie uwarunkowane. Niemniej wyniki badania statystycznego i analizy opisowej wskaźników upoważniają do stwierdzenia, że cel opracowania został zrealizowany. Jego weryfikacja wymaga jednak dalszych badań.

\section{Economic Activity and the Correlation between Taxes and the General Government Sector Debt}

Correlation differences between taxes $(\mathrm{X})$ and tax receipts increased by social insurance contributions (X') and general government sector debt (Y') in the European Union member states have been studied at two different phases of economic development. The intensity of interdependence and the relationships between the variables analysed under different circumstances existing in individual countries turned out to be very varied. In all analyses conducted, a positive correlation coefficient was predominant. This means that the higher the tax burden the lower the tax base, lower public revenues and a higher deficit. At the same time, the lower the tax burden, the lower the deficit and debt. The results obtained in the course of the analyses performed must be interpreted with caution since the categories used in the analyses are subject to a variety of conditions. However, the results of a statistical study and a descriptive analysis allow us to conclude that the objective of the research has been achieved. Studies on its verification though must continue. 